\title{
Increased secretion of pleural fluid after ascending aortic dissection repair
}

\author{
Cezary Danielecki ${ }^{1}$, Paweł Bugajski ${ }^{1}$, Tomasz Poprawka ${ }^{1}$, Krzysztof Greberski ${ }^{1,2}$, Ryszard Kalawski ${ }^{1,2}$ \\ ${ }^{1}$ Oddział Kardiochirurgii Wielospecjalistycznego Szpitala Miejskiego im. Józefa Strusia z Zakładem \\ Opiekuńczo-Leczniczym SP ZOZ, Poznan \\ 2Zakład Profilaktyki Chorób Układu Krążenia, Poznan University of Medical Sciences, Poznan \\ Kardiochirurgia i Torakochirurgia Polska 2013; 10 (2): 158-160
}

\begin{abstract}
The patient was admitted to the Department of Cardiac Surgery of the J. Struś Municipal Hospital in Poznań due to dissection of the ascending aorta and arch. 7 days after the operation, which proceeded without complications, increased secretion of pleural fluid was revealed; the fluid was then evacuated repeatedly. The patient spent 52 days in hospital, including 22 days in the cardiac intensive care unit. Total drainage of the left pleural cavity amounted to $11750 \mathrm{ml}$, and of the right $-4750 \mathrm{ml}$. The left pleural cavity was drained nine times, while the right was drained five times. The catheters from both pleural cavities were exchanged several times due to their obstruction. The patient was intubated five times because of deteriorating arterial blood gas results, and he required approximately 80 hours of mechanical ventilation. Thoracic surgery, radiological consultation, and chest $\mathrm{CT}$ did not reveal any tangible causes of that condition; therefore, only symptomatic treatment was applied.
\end{abstract}

Key words: aortic dissection, pleural fluid.

\section{Introduction}

In the case of ascending aortic dissection (Stanford type A, DeBakey type I and II), surgical treatment is a life-saving procedure. Surgery must be undertaken as soon as possible, as the increase in mortality for each consecutive hour after the presentation of symptoms is estimated at $1-2 \%$ [1-3]. In spite of advances in the field of cardiac surgery, resulting in increasingly positive results of conducted procedures, the less frequent complications should also be kept in mind. One such complication is the increased secretion of pleural fluid during the postoperative period $[4,5]$. The pleura is a thin serous membrane consisting of two layers: the parietal

\section{Streszczenie}

Pacjent został przyjęty na Oddział Kardiochirurgii Wielospecjalistycznego Szpitala Miejskiego im. J. Strusia w Poznaniu z powodu tętniaka rozwarstwiającego aorty wstępującej i łuku. U chorego po operacji, która przebiegła początkowo bez powikłań, od 7. doby nastąpiło wzmożone wydzielanie płynu opłucnowego, który wielokrotnie ewakuowano. Pacjent spędzit na Oddziale 52 doby, z czego 22 doby $w$ sali o intensywnym nadzorze kardiologicznym. Łączny drenaż lewej jamy opłucnowej wyniósł ok. $11750 \mathrm{ml}$, a prawej ok. $4750 \mathrm{ml}$. Lewą jamę opłucnową drenowano 9-krotnie, prawą natomiast 5-krotnie. Cewniki w obu jamach opłucnowych kilkukrotnie wymieniano ze względu na ich niedrożność oraz złą tolerancją wkłuć przez chorego. Z powodu pogarszających się wartości gazometrii krwi tętniczej pacjent był 5-krotnie intubowany, wymagając łącznie ok. 80 godzin respiratoroterapii. Kilkukrotne konsultacje torakochirurgiczne, radiologiczne oraz liczne badania dodatkowe, w tym tomografia komputerowa klatki piersiowej, nie ujawnity żadnych uchwytnych przyczyn wystąpienia omawianego powikłania, w związku z czym ograniczono się do leczenia objawowego.

Słowa kluczowe: rozwarstwienie aorty wstępującej, płyn opłucnowy.

pleura, adhering to the pectoral fascia, the mediastinum, and the diaphragm, and the visceral pleura, which covers the lung [6]. Between them, there is a thin space filled with a small amount of fluid (10-15 ml), which allows the pleurae to maintain adherence and to slide against each other. The fluid is primarily produced and absorbed by the parietal pleura; disturbances in the balance between production and reabsorption lead to its accumulation in the pleural cavity [7].

\section{Aim of the study}

The aim of the study is to present the protocol for treating prolonged pleural fluid secretion after a Bentall procedure.

Address for correspondence: Cezary Danielecki, Oddział Kardiochirurgii Wielospecjalistycznego Szpitala Miejskiego im. Józefa Strusia z Zakładem Opiekuńczo-Leczniczym SP ZOZ, ul. Szwajcarska 3, 61-285 Poznań, tel. +48 510098 953, e-mail: czarekdanielecki@interia.pl 


\section{Case study}

The patient, aged 63, was urgently admitted to the cardiac surgery department of the J. Struś Municipal Hospital in Poznań due to the diagnosis of a dissecting aneurysm of the ascending aorta and the aortic arch. CT evaluation revealed a distention of the ascending aorta (to approximately $60 \mathrm{~mm}$ ) and of the aortic arch (to approximately $36 \mathrm{~mm}$ ). The dissection was present in the ascending part of the aorta and the aortic arch, without involving the bulb, and its end was located immediately behind the orifice of the left subclavian artery (the diameter of the descending aorta at this point was up to $30 \mathrm{~mm}$ ). Large fenestration openings could be seen in the proximal and the distal part of the dissection. ECG evaluation of the tricuspid aortic valve demonstrated the following details: annulus width - $23 \mathrm{~mm}$, thickened cusps, regurgitation - grade III, VC $10 \mathrm{~mm}$. It also revealed the aortic aneurysm above the aortic annulus, with the dissection located $17-20 \mathrm{~mm}$ from the annulus. The procedure employed extracorporeal circulation and cannulation of the ascending aorta (in the area of the brachiocephalic artery) and the right atrium. The aorta was clamped and blood cardioplegia was administered, after which the patient underwent aortic dissection repair. An Aortic Carbomedics SORIN AP-025 (Valve Size 25, Graft Diameter 28) conduit was implemented with the grafting of the coronary ostia. The extracorporeal circulation time was 167 minutes, and the aortic clamping time was 107 minutes. After the surgery, the patient was transferred to the intensive postoperative care unit, where he was extubated 8 hours later. The drainage from the mediastinum and both pleural cavities, opened during the surgery, amounted to $400 \mathrm{ml}$ within the first $24 \mathrm{~h}$. During the $3^{\text {rd }}$ postoperative day, after a series of intensive respiratory exercises, both drains were removed. For the next 4 days, the patient remained in good general condition with normal levels of blood morphology and values of arterial blood gas. On the $7^{\text {th }}$ postoperative day, the gas exchange parameters deteriorated; ultrasonographic and radiological examinations of the chest revealed the presence of a significant amount of fluid in both pleural cavities (Fig. 1).

Drainage of the left pleural cavity was performed with an 032" Arrow catheter ( $7^{\text {th }}$ intercostal space, posterior axillary line), resulting in the evacuation of $2600 \mathrm{ml}$ of fluid tinged with blood. Due to similar indications on the 8th postoperative day, the right pleural cavity was tapped, and $1050 \mathrm{ml}$ of fluid, similar in nature, was evacuated. After ultrasound and radiological evaluations of the chest and intensive physical therapy, catheters were removed from both pleural cavities. During the 10th day, the patient's general condition deteriorated again, as did the arterial blood gas values $\left(\mathrm{pO}_{2}: 65 \mathrm{~mm} \mathrm{Hg}, \mathrm{pCO}_{2}: 63 \mathrm{~mm} \mathrm{Hg}\right.$ ), and the patient was intubated once more. On the $11^{\text {th }}$ day, the left pleural cavity was tapped again, and $1100 \mathrm{ml}$ of bright fluid was aspirated. On the $13^{\text {th }}$ day, the patient was extubated and the catheter was removed from the pleural cavity; arterial blood gas values were within the normal range. Another worsening of the patient's general condition occurred on the $14^{\text {th }}$ day and progressed with an increase of $\mathrm{pCO}_{2}$ to $68 \mathrm{~mm} \mathrm{Hg}$ and a decrease of $\mathrm{pO}_{2}$ to $62 \mathrm{~mm} \mathrm{Hg}\left(\mathrm{SaO}_{2} 91 \%\right)$. The patient was, therefore, intubated; a left thoracocentesis was performed, and $600 \mathrm{ml}$ of bright fluid was evacuated. After more than a dozen hours, mechanical ventilation was removed; the satisfactory general condition of the patient and the values of arterial blood gas allowed for the patient's extubation. Diagnostic examination repeated on the 18th day revealed the presence of fluid in both pleural cavities, which were, therefore, subsequently aspirated. After 6 days, on the $24^{\text {th }}$ postoperative day, the condition of the patient deteriorated once more (paroxysmal tachypnea, $\mathrm{pO}_{2}: 43 \mathrm{~mm} \mathrm{Hg}, \mathrm{pCO}_{2}$ : $87 \mathrm{~mm} \mathrm{Hg}$ ). The patient was, therefore, intubated for the fifth time, and another thoracocentesis was performed, evacuating $1600 \mathrm{ml}$ of bright fluid. On the $27^{\text {th }}$ day, the patient was extubated after ultrasound and radiological examination. During the subsequent days, the patient remained in good general condition, and the gas exchange parameters were normal. On the $36^{\text {th }}$ day, suction drainage was applied to the left pleural cavity (Trocar $24 \mathrm{Ch}, 5^{\text {th }}$ intercostal space, median axillary line), as radiological evaluation revealed pneumothorax. After 72 hours, the drain was clamped, and radiological and ultrasonographic examinations were performed; they demonstrated that the drain was moved partially out of the pleural cavity. This was associated with the uncommon lack of subordination and cooperation that the patient had exhibited from the beginning of the therapy. The drain was replaced; during the subsequent days, the pneumothorax subsided, and the amount of fluid in the left pleural cavity was negligible $(20-50 \mathrm{ml} / 24 \mathrm{~h})$. Finally, on the $45^{\text {th }}$ day, suction drainage was removed. Ultrasound and radiological examinations were performed and repeated, after which the patient, in good general condition, was referred for cardiac rehabilitation.

\section{Discussion}

The patient was hospitalized for 52 days, including 22 days in the cardiac intensive care unit. His treatment consisted in repeated drainage of the pleural cavities, in-

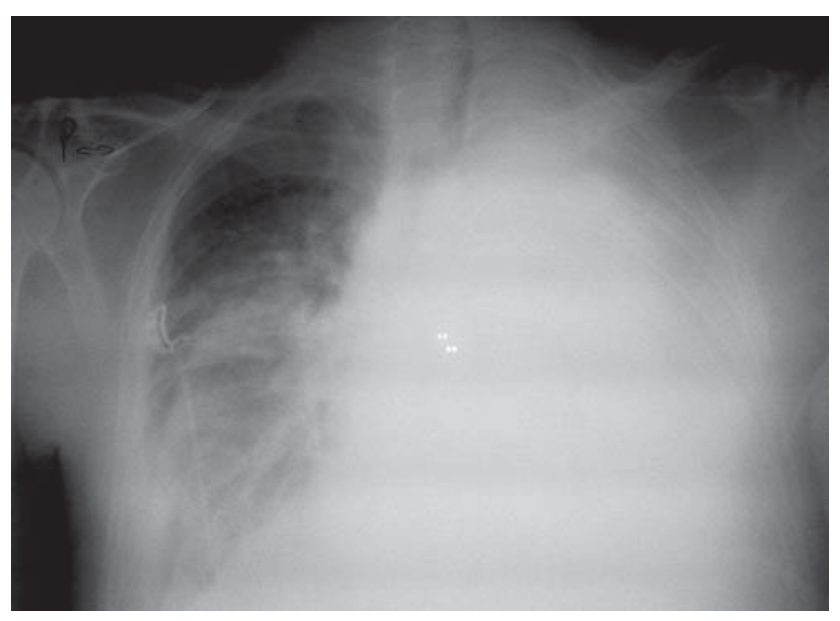

Fig. 1. Radiological examination indicates the presence of a significant amount of fluid in the pleural cavities 
tensive diuretic treatment (furosemide, spironolactone), and intravenous administration of albumins in order to raise the oncotic pressure of blood plasma. The total drainage of the left pleural cavity amounted to $11750 \mathrm{ml}$ and of the right pleural cavity $4750 \mathrm{ml}$. The left pleural cavity was drained 9 times, and the right 5 times. Moreover, catheters had to be replaced several times, due to their obstruction. It should be noted that, despite the repeated tapping of the pleural cavities, significant complications that have been described in similar cases (such as damage to the lungs, arteries, or intercostal nerves, bleeding into the pleural cavity, infection at the puncture site, or pneumothorax) were avoided [8]. Due to the deteriorating gas exchange parameters, the patient was intubated five times, requiring over 80 hours of mechanical ventilation in total. It was difficult to explain the reasons behind the increased, violently occurring and repeated secretion of transudative fluid which turned out to be sterile in bacteriological examination. Postoperative chylothorax was considered as a possible explanation for the complication. Therefore, we contemplated performing pleurodesis by administering talc through a drain into the left pleural cavity (bearing in mind that this therapy may sometimes results in acute respiratory distress syndrome) $[9,10]$. The clarity of the fluid and its consistency did not indicate the presence of lymph. Even so, the patient was substantially weakened, and his total protein and albumin concentrations were at the low end of the normal range, which suggested that we might have been dealing with abnormal lymphatic fluid. However, biochemical analyses of the fluid [triglycerides $0.1 \mathrm{mmol} / \mathrm{l}(8.85$ $\mathrm{mg} / \mathrm{dl}$ ) and cholesterol $1.4 \mathrm{mmol} / \mathrm{l}(54 \mathrm{mg} / \mathrm{dl})$ ] unequivocally excluded the presence of chylothorax [11]. Further analysis confirmed the transudative nature of the fluid (fluid/serum ratio: protein 0.27; LDH 0.50; amylase 0.25) [12]. Proteinuria, which could have induced the fluid secretion by leading to a decrease in oncotic pressure, was also excluded during the therapy. Numerous consultations and additional examinations performed as soon as the complication was diagnosed did not reveal its origin; therefore, only symptomatic treatment was applied. Based on the case study described above, it can be ascertained that increased fluid secretion in the pleural cavities is one of the complications that can occur after extensive cardiac surgery [5], and that repeated aspiration of the pleural cavities turned out to be an efficacious treatment. In our view, this case also suggests that transthoracic ultrasonographic evaluation is a valuable method of determining the amount of fluid in the pleural cavities [13], as, during the hospitalization, the subsequent results of radiological and ultrasonographic examinations were exceptionally consistent concerning the amount and character of the fluid.

\section{References}

1. Emmett $M$. Predicting death in patients with acute type a aortic dissection. Circulation 2002; 106: e224.

2. Kłosiewicz-Wąsek B. Tętniak rozwarstwiający aorty. Post Nauk Med 2007; 2-3: 80-82.

3. Hagan PG, Nienaber CA, Isselbacher EM, Bruckman D, Karavite DJ, Russman PL, Evangelista A, Fattori R, Suzuki T, Oh JK, Moore AG, Malouf JF, Pape LA, Gaca C, Sechtem U, Lenferink S, Deutsch HJ, Diedrichs H, Marcos y Robles J, Llovet A, Gilon D, Das SK, Armstrong WF, Deeb GM, Eagle KA. The International Registry of Acute Aortic Dissection (IRAD): New insights into an old disease. JAMA 2000; 283: 897-903.

4. Labidi M, Baillot R, Dionne B, Lacasse Y, Maltais F, Boulet LP. Pleural effusions following cardiac surgery. Chest 2009; 136: 1604-1611.

5. Light RW. Pleural effusions following cardiac injury and coronary artery bypass graft surgery. Semin Respir Crit Care Med 2001; 22: 657-664.

6. Moore KL, Halley AF (eds.). Clinically oriented anatomy, $4^{\text {th }}$ ed. Lippincott Williams \& Wilkins, Baltimore 1999.

7. Kozielski J. Płyny opłucnowe - punkt widzenia pulmonologa. Przew Lek 2008; 1: 27-30.

8. Miller S, Sahn A. Chest tubes. Indications, technique, management and complications. Chest 1987; 91: 258-264.

9. Drozdowska A, Jassem E. Management of recurrent pleural exudates in neoplastic diseases. Pol Med Paliat 2003; 2: 227-233.

10. Kennedy L, Sahn SA. Talc pleurodesis for the treatment of pneumothorax and pleural effusion. Chest 1994; 106: 1215-1222.

11. Rokicki W, Rokicki M, Filipowski M, Wojtacha J, Zygo A. Chłonkotok (chylothorax) jako problem torako- i kardiochirurgiczny. Część II. Metody leczenia chłonkotoku. Algorytm postępowania. Kardiochir Torakochirur Pol 2011; 8: 361-365.

12. Light's Criteria

13. Usta E, Mustafi M, Ziemer G. Ultrasound estimation of volume of postoperative pleural effusion in cardiac surgery patients. Interact Cardiovasc Thorac Surg 2010; 10: 204-207. 